
p-ISSN: 0436-0265 e-ISSN: 2528-5874

\title{
ASUPAN NATRIUM PENDUDUK INDONESIA: \\ Analisis Data Survei Konsumsi Makanan Individu (SKMI) 2014
}

\author{
Sodium Intake among Indonesian Population: \\ Analysis of Individual Food Consumption Survey 2014
}

\author{
Sri Prihatini, Dewi Permaesih, Elisa Diana Julianti \\ Pusat Penelitian dan Pengembangan Upaya Kesehatan Masyarakat, Badan Penelitian dan \\ Pengembangan Kesehatan, Kementerian Kesehatan RI \\ Jl. Percetakan Negara No.29 Jakarta Pusat \\ E-mail: sriprihatini58@yahoo.com
}

\begin{abstract}
Hypertension, heart disease and stroke become a major cause of death in Indonesia. Many studies showed that there were a relationship between excess of sodium intake and the incidence of hypertension. Globally, excess of sodium intake were responsible for 1,7 million death from cardiovascular diseases. The Regulation of Minister of Heath of the Republic of Indonesia of the year of 2013 recommends to decrease sodium intake approximately $2 \mathrm{gram}$ of sodium per day. This study aimed to estimate sodium intake among Indonesian population using Indonesian Food Consumption Survey data in 2014. Data collection used 24-hour recall method. Descriptive analysis was conducted using 145,360 subjects from 33 provinces in Indonesia. The study showed that the average sodium intake was $2764 \mathrm{mg} /$ day, 52.7 percent of the population consumed more than $2000 \mathrm{mg} /$ day, 73 percent sodium intake came from home-cooked meal and 23 percent from processed foods. Estimated 47,6 percent intake of sodium naturally occurred in foods and 52,4 percent from salt added into food. The average salt intake among Indonesian population aged 5 years and above has exceeded the recomendation limit.
\end{abstract}

Keywords: sodium intake, salt, Indonesian population

\section{ABSTRAK}

Saat ini hipertensi, jantung dan stroke menjadi penyebab utama kematian di Indonesia. Banyak penelitian menunjukkan kaitan antara asupan natrium dan kejadian hipertensi. Setiap tahunnya sekitar 1,7 juta kematian akibat penyakit kardiovaskular selalu dikaitkan dengan kelebihan assupan natrium. Mengingat dampak buruknya, WHO dan pemerintah Indonesia melalui Permenkes nomor 30 tahun 2013 merekomendasikan penurunan konsumsi garam di bawah $5 \mathrm{~g}$ per hari atau sekitar $2 \mathrm{~g}$ natrium per hari untuk mencegah kejadian hipertensi dan risiko penyakit jantung dan stroke. Tujuan penelitian ini adalah untuk mendapatkan informasi mengenai jumlah asupan natrium pada penduduk Indonesia dari data Survei Konsumsi Makanan Individu (SKMI) 2014. Pengumpulan data dilakukan dengan metode food recall 1x 24 jam. Analisis deskriptif dilakukan pada sampel sebanyak 145.360 orang, yang tersebar di 33 provinsi di Indonesia. Hasil studi menunjukkan bahwa rerata asupan natrium penduduk Indonesia sebesar 2764 $\mathrm{mg} /$ orang/hari. Sekitar 52,7 persen penduduk Indonesia mengonsumsi natrium $>2000 \mathrm{mg} / \mathrm{hari}$. Sebanyak 73 persen natrium berasal dari makanan yang dimasak di rumah dan 23 persen dari makanan yang dibeli di luar rumah. Kontribusi asupan natrium berasal dari bahan makanan sebesar 47,6 persen dan 52,4 persen dari garam. Kesimpulan: Rata-rata asupan natrium penduduk Indonesia usia di atas 5 tahun sudah melebihi $2000 \mathrm{mg} / \mathrm{hari}$ atau melebihi batas yang dianjurkan.

Kata kunci: Asupan natrium, garam, penduduk Indonesia 


\section{PENDAHULUAN}

S aat ini Indonesia masih mengalami masalah kekurangan gizi dan masalah kegemukan serta peningkatan prevalensi penyakit kronis. Hasil Survei Sampel Registry 2014 menunjukkan bahwa stroke menduduki peringkat pertama dari 10 penyebab kematian $(21,1 \%)$, penyakit jantung dan pembuluh darah pada peringkat kedua $(12,9 \%)$, dan peringkat ketiga komplikasi tekanan darah tinggi $(5,3 \%)$. Data WHO menyimpulkan bahwa kelebihan asupan natrium berkaitan dengan peningkatan kejadian hipertensi dan penyakit kardiovaskular. Setiap tahunnya sekitar 1,7 juta kematian akibat penyakit kardiovaskular selalu dikaitkan dengan kelebihan asupan natrium. Salah satu faktor risiko kejadian penyakit kardiovaskular adalah hipertensi. ${ }^{1-2}$

Hipertensi sering disebut sebagai the silent killer karena umumnya penderita tidak mengetahui dirinya mengidap hipertensi sebelum memeriksakan tekanan darahnya. Hipertensi dikenal juga sebagai heterogeneous group of disease karena dapat menyerang siapa saja dari berbagai kelompok umur dan kelompok sosial-ekonomi. Menurut hasil RISKESDAS berdasarkan pengukuran di tahun 2007 dan 2013, prevalensi hipertensi di Indonesia menunjukkan penurunan dari 31,7 persen menjadi 25,8 persen. ${ }^{3-4}$ Asumsi penurunan diperkirakan karena (i) perbedaan alat ukur yang digunakan tahun 2007, tidak diproduksi lagi (discontinue) pada tahun 2013; (ii) kesadaran masyarakat yang makin membaik pada tahun 2013.4

Faktor pemicu hipertensi dapat dibedakan menjadi yang tidak dapat dikontrol, seperti keturunan, jenis kelamin dan umur, serta faktor yang dapat dikontrol, seperti kegemukan, kurang olahraga, merokok, dan konsumsi makanan/minuman. Hipertensi dapat dicegah dengan pengaturan pola makan yang baik dan aktivitas fisik yang cukup. Salah satu faktor yang memiliki hubungan erat dengan terjadinya hipertensi adalah asupan natrium $(\mathrm{Na})$. Penurunan $\mathrm{Na}$ di dalam urine sebesar 1,8 gram per hari berbanding lurus dengan penurunan tekanan darah; (1) sistol sebesar $2 \mathrm{mmHg}$ dan 1 $\mathrm{mmHg}$ untuk tekanan darah diastol pada pasien non-hipertensi, (2) $5 \mathrm{mmHg}$ untuk tekanan darah sistol dan 2,7 mmHg untuk tekanan darah diastol pada pasien hipertensi. ${ }^{5-6-7}$
Dalam upaya pencegahan terhadap penyakit kronis atau penyakit tidak menular (PTM), pemerintah melalui Permenkes No. 30 Tahun 2013 menetapkan pencantuman informasi kandungan gula, garam, dan lemak serta pesan kesehatan untuk pangan olahan dan pangan siap saji. Pesan kesehatan yang dimaksud adalah konsumsi gula lebih dari 50 gram (g), natrium lebih dari 2000 miligram (mg), dan lemak total lebih dari $67 \mathrm{~g}$ per orang per hari berisiko hipertensi, stroke, diabetes, dan serangan jantung. ${ }^{8}$

Pada tahun 2014, Badan Penelitian dan Pengembangan Kesehatan (Badan Litbangkes) Kementerian Kesehatan RI telah melakukan Survei Konsumsi Makanan Individu (SKMI), di antaranya mengumpulkan konsumsi bumbu, termasuk garam, dan menghitung asupan natrium dari bahan makanan selain garam. Pada tulisan ini disajikan hasil analisis data mengenai sumber dan jumlah asupan natrium penduduk Indonesia menurut kelompok umur.

\section{METODE PENELITIAN}

Data yang digunakan untuk analisis ini berasal dari data SKMI 2014 yang dilakukan Badan Litbangkes. Jumlah seluruh sampel yang dianalisis berjumlah 145.360 orang yang tersebar di 33 provinsi di Indonesia. Data konsumsi makanan dikumpulkan dengan metode food recall 1x 24 jam. Jumlah asupan natrium dihitung dari kandungan natrium seluruh bahan makanan, termasuk penggunaan bumbu dan garam yang dikonsumsi per orang per hari, dengan menggunakan Daftar Komposisi Bahan Makanan SKMI 2014. Data dianalisis secara deskriptif.

Dalam studi SKMI 2014, cara memperkirakan penggunaan bumbu, termasuk garam pada makanan yang dikonsumsi dan berasal dari makanan di rumah, dilakukan dengan pendekatan penambahan garam pada saat pengolahan makanan di tingkat rumahtangga. Perhitungan jumlah garam yang dikonsumsi per orang adalah jumlah garam yang ditambahkan pada saat pengolahan makanan, dibagi jumlah anggota rumah-tangga. Khusus untuk anak balita, perkiraannya adalah sepertiga dari orang dewasa. Sementara untuk jenis makanan siap saji, jumlah garam yang dikonsumsi adalah sejumlah garam yang ditambahkan pada hidangan tersebut. 
Dalam tulisan ini selanjutnya, rerata jumlah asupan natrium disetarakan ke dalam garam. Adapun cara perhitungannya adalah sebagai berikut: Dalam 1 gram garam mengandung sekitar $400 \mathrm{mg}$ natrium. Misalkan, rerata asupan natrium penduduk sebesar $2400 \mathrm{mg}$, maka asupannya setara dengan $2400 / 400=6$ gram garam. Data dianalisis secara deskriptif.

\section{HASIL}

Pada Tabel 1 disajikan distribusi sampel menurut karakteristik. Jumlah seluruh sampel yang dianalisis sebanyak 145.360 orang. Persentase terbesar terlihat pada kelompok umur dewasa $(61,0 \%)$ dan terkecil pada anak balita $(4,2 \%)$. Jumlah sampel laki-laki sedikit lebih banyak dari perempuan. Jumlah sampel yang tinggal di perkotaan lebih banyak dari perdesaan. Berdasarkan status ekonomi, jumlah sampel menengah atas terlihat lebih banyak dari status ekonomi lainnya.

Pada Gambar 1 disajikan rerata asupan natrium penduduk Indonesia menurut kelompok umur. Rata-rata asupan natrium penduduk Indonesia secara keseluruhan adalah $2674 \mathrm{mg}$ per orang per hari. Rerata asupan natrium tertinggi, yakni sebesar $2748 \mathrm{mg}$ per orang per hari, terlihat pada kelompok umur 13-18 tahun (remaja) dan terendah pada kelompok umur < 5 tahun (balita), yaitu sebesar $1473 \mathrm{mg}$ per orang per hari. Rerata asupan natrium terlihat cenderung menurun pada usia lebih dari 55 tahun.

Pada Tabel 2 disajikan proporsi penduduk yang mengonsumsi natrium lebih dari $2000 \mathrm{mg}$ per hari. Dalam upaya pencegahan terhadap PTM, pemerintah melalui Permenkes Nomor 30 Tahun 2013 menetapkan pencantuman informasi kandungan gula, garam, dan lemak serta pesan kesehatan untuk pangan olahan dan pangan siap saji. Untuk asupan natrium ditetapkan batas $2000 \mathrm{mg}$ per orang per hari atau setara dengan 5 gram garam.

Dari hasil SKMI ini terlihat bahwa sebanyak 52,7 persen penduduk mengonsumsi lebih dari $2000 \mathrm{mg}$ per orang per hari. Proporsi penduduk yang mengonsumsi natrium lebih dari $2000 \mathrm{mg}$, terlihat paling tinggi pada kelompok usia 13-18 tahun $(55,7 \%)$ dibandingkan dengan kelompok umur lainnya. Proporsinya terlihat lebih tinggi pada laki-laki $(53,4 \%)$ dibandingkan dengan perempuan, kemudian pada penduduk yang tinggal di perkotaan $(54,6 \%)$ dan penduduk berstatus ekonomi menengah atas $(55,7 \%)$.

Pada Gambar 2 disajikan persentase asupan natrium menurut sumber perolehan makanan. Dalam memperoleh makanan yang dikonsumsi sampel, sumber makanan dapat diperoleh dari makanan yang dimasak di rumahtangga atau makanan yang dibeli di luar rumah atau makanan dari pemberian orang lain. Secara keseluruhan, sebanyak 73,2 persen dari asupan natrium berasal dari makanan yang dimasak di rumah, hanya sekitar 23,2 persen yang diperoleh dari makanan yang dibeli di luar rumah; sisanya berasal dari pemberian $(3,6 \%)$.

Natrium adalah zat gizi mikro, yang bukan hanya bersumber dari garam dapur saja, tetapi juga banyak terdapat di dalam bahan makanan lain yang dikonsumsi. Pada Gambar 3 di atas disajikan kontribusi asupan natrium yang berasal dari bahan makanan dan penambahan garam saat pengolahan makanan di rumah. Pada anak balita, sebagian besar asupan natrium $(60,3 \%)$ berasal dari bahan makanan. Pada usia lebih dari 5 tahun, kontribusi natrium dari bahan makanan semakin kecil dan terendah pada penduduk usia lebih dari 55 tahun (39\%). Sebaliknya, kontribusi natrium berasal dari garam semakin meningkat dengan bertambahnya usia.

Pada Gambar 4 disajikan rerata konsumsi garam ( $\mathrm{NaCl}$, tidak termasuk natrium) penduduk menurut kelompok umur. Penggunaan garam dapur dalam hidangan penduduk Indonesia pada umumnya melalui penambahan pada proses pemasakan di rumah atau penambahan saat mengonsumsi makanan siap saji. Rerata konsumsi garam penduduk Indonesia sebesar 3,5 gram per orang per hari. Konsumsi garam terlihat paling rendah pada kelompok umur balita, yakni 1,5 gram per orang per hari. Konsumsi tertinggi terlihat pada kelompok umur dewasa lebih dari 19 tahun, yaitu 3,7 gram per orang per hari. Konsumsi garam terlihat meningkat dengan bertambahnya usia.

Pada Gambar 5 disajikan rerata asupan natrium penduduk yang disetarakan dengan garam. Pada Gambar 1 di atas telah disajikan rerata asupan natrium penduduk menurut kelompok umur. Jumlah asupan natrium ini diperoleh, baik pangan berasal dari bahan makanan maupun dari garam dapur yang ditambahkan. Selanjutnya, dihitung seluruh asupan natrium, baik yang berasal dari bahan 
makanan maupun dari garam dapur, $\mathrm{NaCl}$ ) terlihat paling rendah pada kelompok disetarakan ke dalam bentuk garam. Dalam 1 gram garam terkandung sekitar $400 \mathrm{mg}$ natrium.

Apabila seluruh asupan natrium yang dikonsumsi dikonversikan ke dalam bentuk garam, maka terlihat rerata asupan natrium $(\mathrm{Na}$ dan $\mathrm{NaCl}$ ) penduduk Indonesia adalah 6,7 gram per orang per hari. Asupan natrium ( $\mathrm{Na}$ dan umur balita, yakni 3,8 gram garam, dan tertinggi terlihat pada kelompok umur 13-18 tahun dan 19-55 tahun, yaitu sekitar 7 gram per orang per hari. Artinya, konsumsi garam penduduk Indonesia secara rata-rata sudah melebihi batas yang dicantumkan dalam pesan Permenkes No. 30 tahun 2013, yakni <5 gram per hari.

Tabel 1

Distribusi Sampel menurut Karakteristik

\begin{tabular}{lcc}
\hline Karakteristik & $\mathrm{n}$ & $\%$ \\
\hline Kelompok umur & & \\
$-\quad 0-59 \mathrm{bln}$ & 6.093 & 4,2 \\
$-\quad 5-12$ thn & 14.871 & 10,2 \\
$-13-18$ thn & 17.228 & 11,9 \\
- $19-55$ thn & 88.634 & 61,0 \\
- > 55 thn & 18.533 & 12,8 \\
Jenis kelamin & & \\
- Laki-laki & 73.011 & 50,2 \\
- Perempuan & 72.348 & 49,8 \\
Tempat tinggal & & \\
- Perkotaan & 73.000 & 50,2 \\
- Perdesaan & 72.360 & 49,8 \\
Kuntil kepemilikan & & 14,9 \\
- Terbawah & 21.740 & 18,9 \\
- Menengah bawah & 27.431 & 21,8 \\
- Menengah & 31.746 & 23,7 \\
- Menengah atas & 34.537 & 20,6 \\
- Teratas & 29.906 & \\
\hline Total & 145.360 & \\
\hline
\end{tabular}

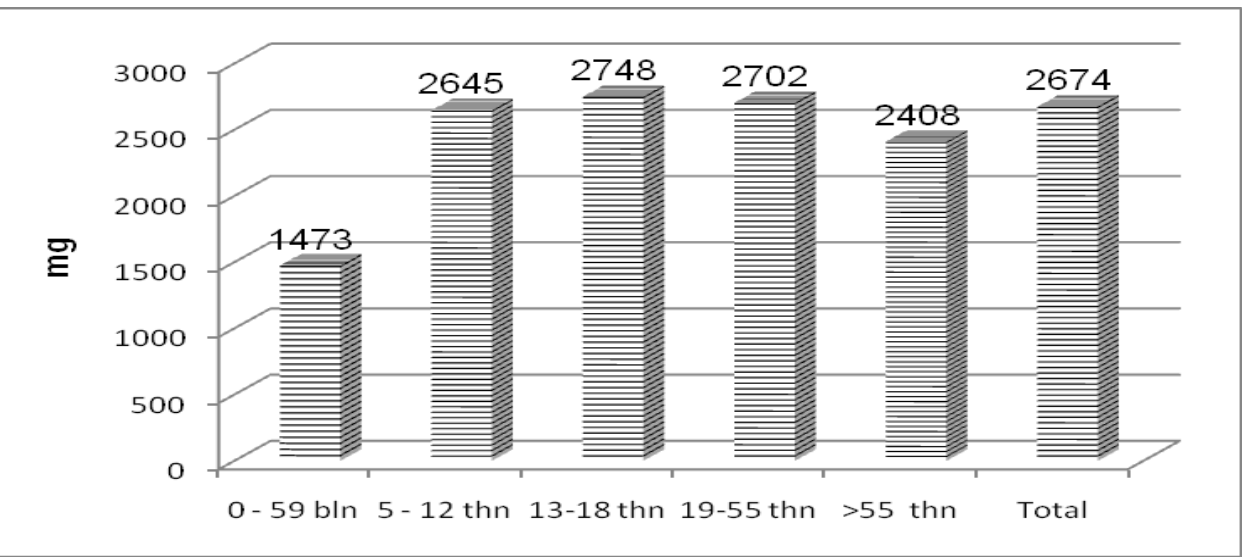

Gambar 1

Rerata Asupan Natrium (mg) menurut Kelompok Umur 
Tabel 2

Proporsi Penduduk Mengonsumsi Natrium $\geq 2000$ mg menurut Karakteristik Sampel

\begin{tabular}{lll}
\hline \multirow{2}{*}{ Karakteristik } & \multicolumn{2}{c}{ Asupan Natrium } \\
\cline { 2 - 3 } Kelompok umur & $<2000 \mathrm{mg}$ & $\geq 2000 \mathrm{mg}$ \\
$-\quad 0-59 \mathrm{bln}$ & 75,4 & 24,6 \\
$-\quad 5-12 \mathrm{thn}$ & 44,8 & 55,2 \\
$-13-18 \mathrm{thn}$ & 44,3 & 55,7 \\
- $19-55 \mathrm{thn}$ & 45,2 & 54,8 \\
- > 55 thn & 52,8 & 47,2 \\
Jenis kelamin & & \\
- Laki-laki & 46,6 & 53,4 \\
- Perempuan & 48,1 & 51,9 \\
Tempat tinggal & & \\
- Perkotaan & 45,4 & 54,6 \\
- Perdesaan & 49,3 & 50,7 \\
Kuntil kepemilikan & & 44,5 \\
- Terbawah & 55,5 & 51,9 \\
- Menengah bawah & 48,1 & 53,1 \\
- Menengah & 46,9 & 55,7 \\
- Menengah atas & 44,3 & 55,4 \\
- Teratas & 44,6 & 52,7 \\
\hline Total & 47,3 & \\
\hline
\end{tabular}

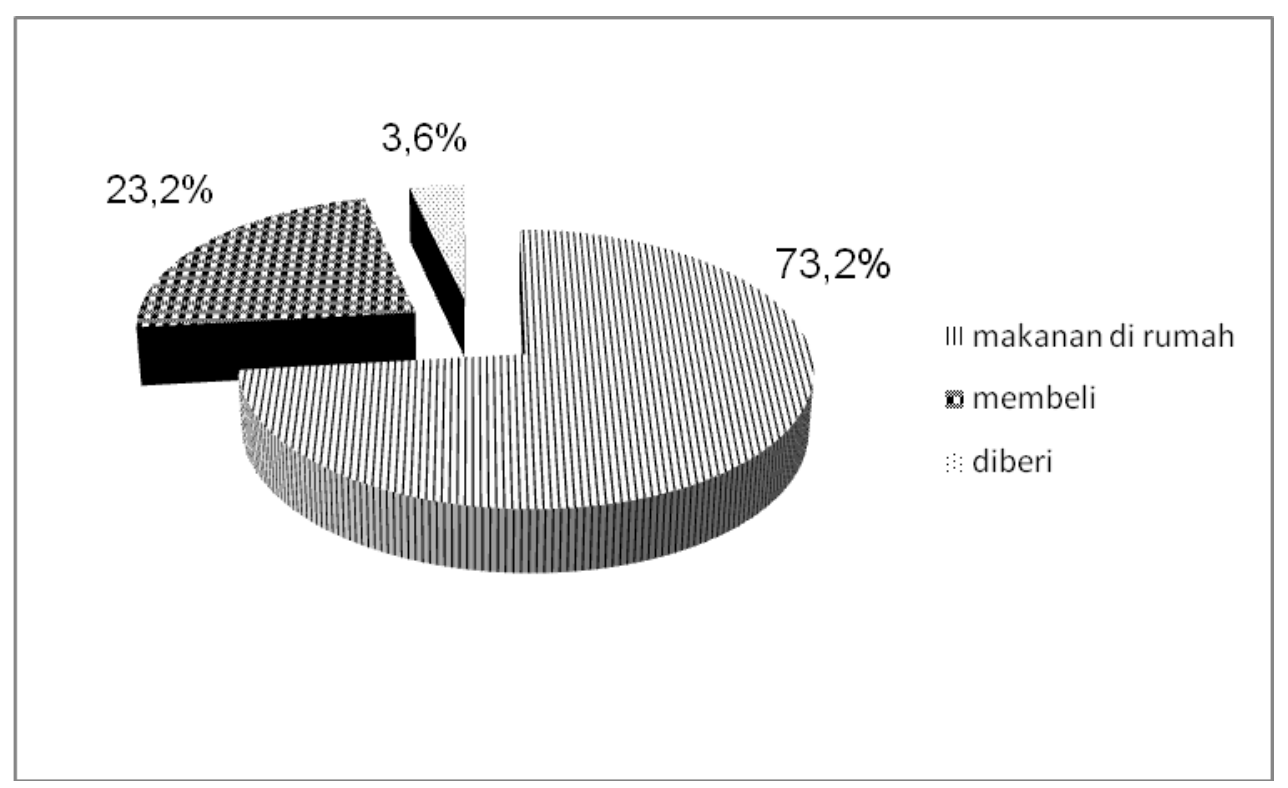

Gambar 2

Persentase Asupan Natrium menurut Sumber Makanan 


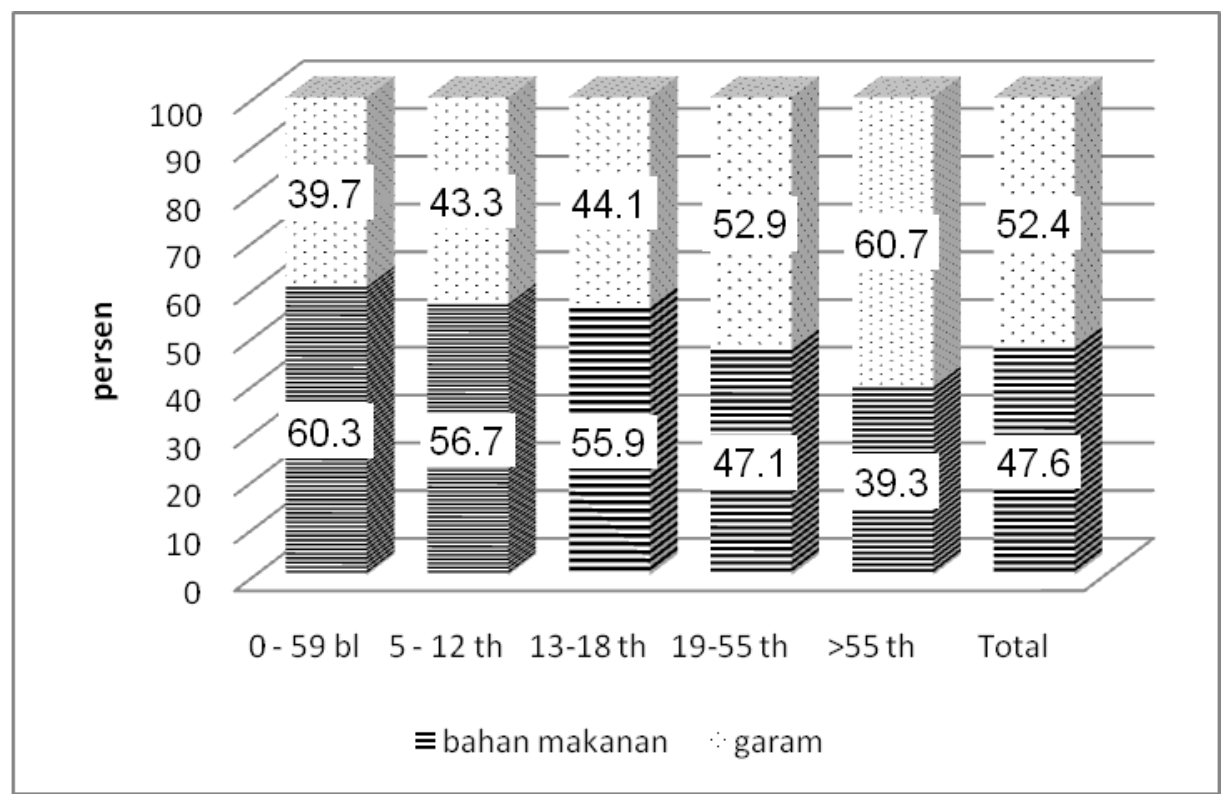

\section{Gambar 3}

Kontribusi Asupan Natrium (\%) dari Bahan Makanan dan Garam

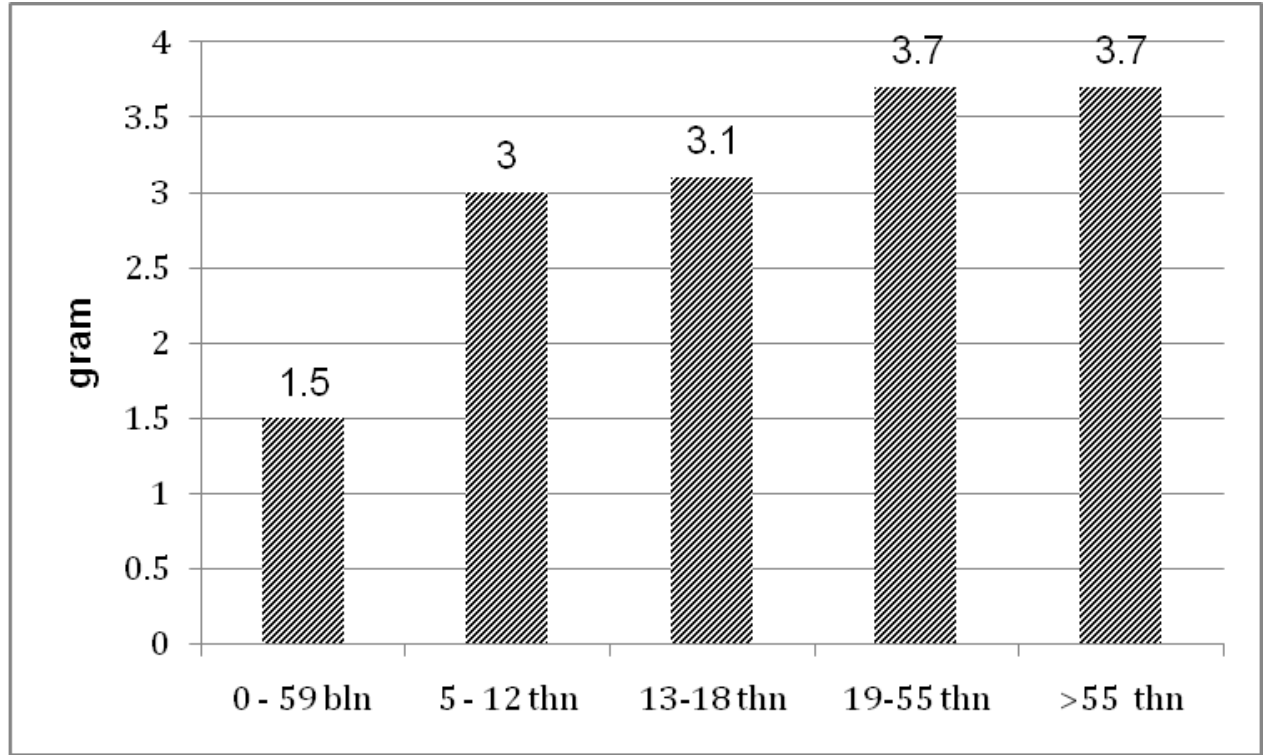

Gambar 4

Rerata Konsumsi Garam/ $/ \mathrm{NaCl}$ (gram) Penduduk menurut Kelompok Umur 


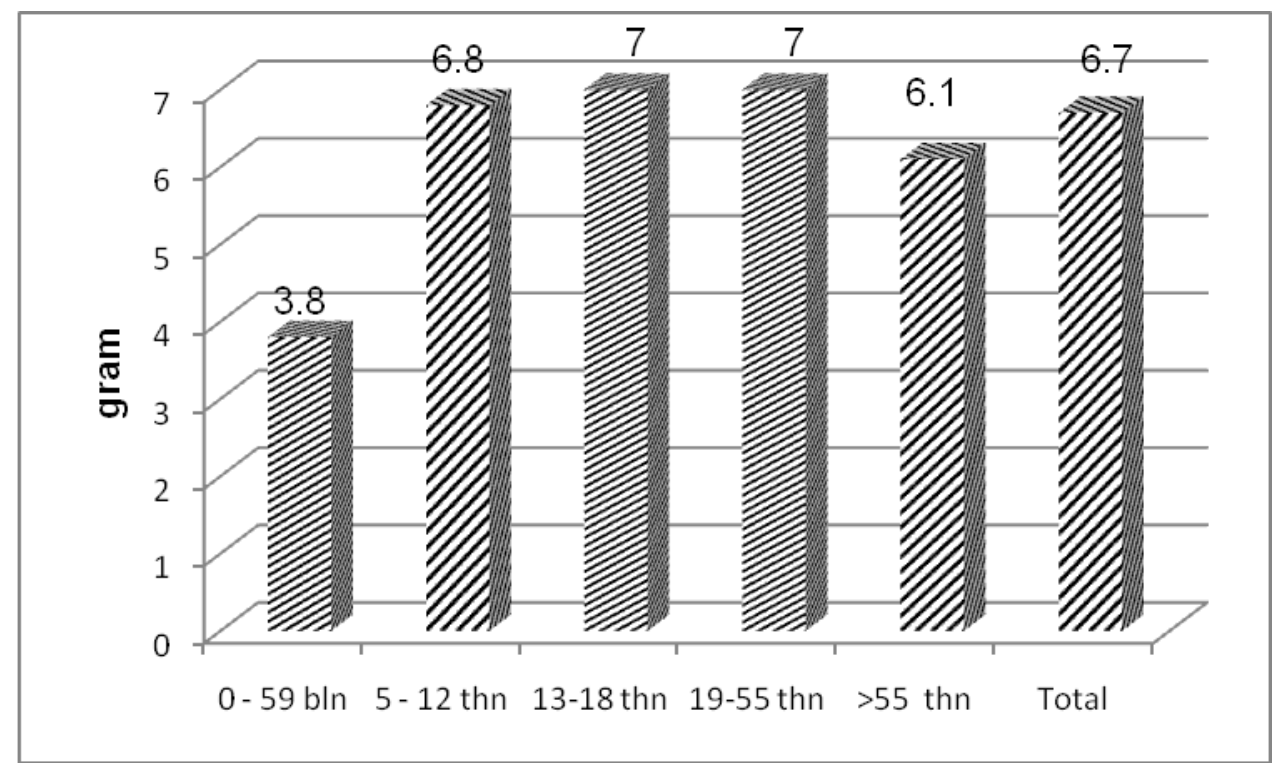

Gambar 5

Rerata Konsumsi Natrium/Na, termasuk $\mathrm{NaCl}$ (gram), Penduduk menurut Kelompok Umur

\section{BAHASAN}

Natrium (sodium) merupakan salah satu mineral penting bagi tubuh. Natrium memegang peran penting dalam tubuh manusia. Namun, konsumsi yang berlebihan akan berdampak negatif bagi tubuh. Hampir semua bahan makanan mengandung natrium, baik yang secara alami terkandung di dalamnya maupun yang ditambahkan melalui proses pemasakan. Oleh karena itu, defisiensi natrium sangat jarang terjadi. Sebaliknya, kelebihan asupan natrium sering menjadi penyebab munculnya berbagai macam penyakit, sehingga kelebihan asupan natrium perlu diwaspadai dengan mencermati pola makan sehari-hari.

Hasil analisis data SKMI 2014 menunjukkan, rerata konsumsi garam penduduk Indonesia sudah melebihi $2000 \mathrm{mg}$ per orang per hari atau melebihi batas yang ditetapkan dalam Permenkes No. 30 tahun 2013. Proporsi penduduk yang mengonsumsi natrium $>2000$ $\mathrm{mg}$ per hari atau setara dengan garam $>5 \mathrm{gram}$ per hari sebesar 52,7 persen. Bahkan, proporsi tertinggi terlihat pada kelompok umur 13-18 tahun, yakni sebesar 55,7 persen. Keadaan ini perlu diwaspadai karena bila tidak dilakukan pencegahan dapat meningkatkan risiko terjadinya hipertensi di masa mendatang. Hasil Riskesdas tahun 2013 menunjukkan, prevalensi hipertensi sebesar 25,8 persen dan hipertensi merupakan penyebab kematian tertinggi $(21,1 \%))^{4-9}$

National Research Council of the National Academy of Sciences merekomendasikan asupan natrium per hari sebanyak 1100-3300 $\mathrm{mg}$. Jumlah tersebut setara dengan $1 / 2-1 \frac{1}{2}$ sendok teh garam dapur per hari. American Heart Association (AHA) merekomendasikan asupan natrium bagi orang dewasa tidak lebih dari $2400 \mathrm{mg} / \mathrm{hari}$, yaitu setara dengan satu sendok teh garam dapur sehari. Tingkat asupan natrium di Amerika Serikat mencapai 4000-5000 $\mathrm{mg} / \mathrm{hari}$. Tingginya asupan natrium di AS disebabkan tingginya konsumsi fast-food, sehingga hipertensi di sana menjadi pembunuh yang paling mematikan. ${ }^{10-11}$ Hasil Randomized Control Trial (RCT) pada penduduk dewasa di Amerika, dengan pengukuran natrium dalam urine 24 jam, menunjukkan bahwa pengurangan jumlah konsumsi garam berhubungan erat dengan penurunan kejadian penyakit kardiovaskular. Penurunan sebesar 25-30 persen konsumsi garam dari sekitar $10 \mathrm{~g} / \mathrm{hari}$ dapat menurunkan 25 persen kejadian penyakit kardiovasular. ${ }^{12-13}$

Hasil analisis data ini menunjukkan bahwa bila dilihat dari sumber perolehan makanan ternyata sekitar 73,2 persen asupan natrium diperoleh dari makanan yang dimasak di rumah dan sekitar 23 persen dari makanan yang dibeli. Keadaan di Indonesia hampir serupa dengan 
hasil studi konsumsi natrium di negara Asia lainnya. Di Jepang dan China, sebanyak 75 persen asupan natrium berasal dari penambahan garam saat memasak dan 25 persen berasal dari saus, termasuk kecap dan miso. ${ }^{14}$

Gambaran asupan natrium di negara Asia agak berbeda dengan Amerika dan Inggris. Di negara maju, seperti Amerika Serikat dan Inggris, diperkirakan sekitar 74 persen asupan sodium berasal dari makanan olahan dan makanan restoran, 10-12 persen berasal dari natrium yang terkandung secara alami dalam makanan, dan 10-15 persen berasal dari penambahan garam dalam proses pemasakan di rumah tangga. ${ }^{15-16}$

Pada tahun 2010, diperkirakan tingkat ratarata konsumsi natrium di seluruh dunia sebesar 3,95 gram per hari, dengan kisaran antara 2,185,51 gram per hari. Secara global, 99,2 persen populasi orang dewasa di dunia memiliki ratarata asupan natrium melebihi rekomendasi WHO (> 2 g/hari). ${ }^{17-19}$ Hasil analisis SKMI menunjukkan, rata-rata asupan natrium orang dewasa sebesar $2702 \mathrm{mg}$ per hari atau 2,7 gram telah melebihi rekomendasi WHO.

Secara keseluruhan rata-rata asupan natrium penduduk Indonesia sebesar $2674 \mathrm{mg}$, yakni sekitar 52,4 persen natrium berasal dari penambahan garam dalam proses pemasakan dan 47,6 persen dari natrium yang terkandung alami dalam bahan makanan serta dari makanan olahan. Untuk mengurangi asupan natrium yang berasal dari bahan makanan sulit dilakukan karena natrium sudah secara alami terkandung di dalam bahan makanan, kecuali mengurangi dari bahan makanan olahan seperti ikan asin, ikan kalengan, daging olahan, kaldu, penyedap dan lain-lain. Bila sebanyak 73 persen asupan natrium berasal dari makanan di rumah (1952 $\mathrm{mg}$ ), maka pengurangan sebesar 1-1,5 gram garam pada proses pemasakan, sudah dapat menurunkan konsumsi natrium menjadi sekitar $1800 \mathrm{mg}$ atau kurang dari 2000 $\mathrm{mg}$ natrium. Untuk mencegah terjadinya peningkatan kejadian PTM, khususnya hipertensi di masa mendatang, maka perlu dilakukan upaya untuk penurunan konsumsi garam, yaitu dengan mengedukasi para ibu agar mengubah kebiasaan menambahkan garam yang berlebihan pada masakan serta memberikan informasi bahaya mengonsumsi natrium berlebihan.

\section{Kebijakan penurunan konsumsi garam di negara lain}

Pendekatan berbasis populasi untuk mengurangi konsumsi garam telah efektif dilakukan di negara maju dan telah berhasil untuk mengurangi kejadian tekanan darah tinggi. Pada tahun 1950-an, Pemerintah Jepang menerapkan kampanye untuk mengurangi asupan garam mengingat angka kematian akibat stroke yang tinggi. Sepuluh tahun kemudian, konsumsi garam berkurang dari ratarata $13,5 \mathrm{~g}$ /hari menjadi $12,1 \mathrm{~g} /$ hari secara keseluruhan, dan dari $18 \mathrm{~g} / \mathrm{hari}$ menjadi 14 $\mathrm{g}$ /hari di daerah utara Jepang. Menurunnya konsumsi garam mengakibatkan penurunan rata-rata tekanan darah dan menurunkan 80 persen angka kematian karena stroke..$^{21-22}$

Pada 1970-an, pemerintah Finlandia mulai mengampanyekan pendidikan kepada publik untuk mengurangi konsumsi garam dan memberlakukan peraturan pada industri pengolahan makanan untuk memberikan label peringatan pada produk makanan yang mengandung garam tinggi..23-24 Lebih dari 30 tahun kemudian, asupan natrium keseluruhan di Finlandia telah menurun lebih dari 40 persen, dan diikuti dengan penurunan tekanan darah diastol lebih dari $10 \mathrm{mmHg}$, juga terjadi penurunan tingkat kematian akibat penyakit jantung dan stroke sebesar 80 persen. ${ }^{25}$

Di China telah dilakukan studi penggantian garam meja dengan garam pengganti parsial tinggi kalium (mengandung kombinasi natrium, kalium dan magnesium). Hasilnya, studi tersebut menunjukkan, dalam waktu 1 tahun tekanan sistol darah dapat turun sebesar 5,4 mmHg. ${ }^{26}$ Kebijakan mengganti sebagian komposisi garam meja $(\mathrm{NaCl})$ dengan variasi beberapa mineral (gabungan dari natrium, kalium, dan/atau magnesium dan kalsium) telah terbukti memiliki efektivitas yang tinggi dalam mengurangi asupan natrium dan juga menurunkan kejadian tekanan darah tinggi. ${ }^{27-28}$

Di negara berkembang, di mana mayoritas asupan natrium berasal dari penambahan garam dalam proses memasak, intervensi terhadap perilaku kemungkinan akan lebih efektif dalam menurunkan asupan natrium dibandingkan intervensi berbasis populasi. ${ }^{20,11,30}$ 


\section{SIMPULAN DAN SARAN}

\section{Simpulan}

Hasil analisis data menunjukkan bahwa rata-rata konsumsi natrium penduduk usia di atas 5 tahun sudah di atas $2000 \mathrm{mg} /$ orang/hari atau melebihi batas yang ditetapkan dalam Permenkes No. 30 tahun 2013. Proporsi penduduk yang mengkonsumsi natrium $>2000$ mg per hari atau setara dengan 5 gram garam terlihat paling tinggi pada kelompok usia 13-18 tahun yang merupakan generasi muda penerus bangsa. Keadaan ini sudah perlu diwaspadai untuk mencegah semakin meningkatnya PTM di masa mendatang. Sebagian besar asupan natrium penduduk berasal dari garam yang ditambahkan saat memasak dan pada makanan siap saji. Oleh karena itu, salah satu cara untuk mencegah asupan natrium yang berlebihan dapat dilakukan melalui edukasi di sekolahsekolah atau kampanye di masyarakat untuk mengurangi garam yang ditambahkan, baik saat proses pemasakan atau saat mengonsumsi makanan siap saji.

\section{Saran}

Untuk penelitian yang akan datang, untuk memperkirakan konsumsi garam individu, disarankan dilakukan melalui pendekatan dari makanan yang dikonsumsi oleh individu tersebut, bukan melalui perkiraan masakan di tingkat rumah tangga sehingga perkiraannya lebih mendekati.

\section{UCAPAN TERIMA KASIH}

Ucapan terima kasih kami sampaikan kepada Badan Litbangkes, yang telah memberikan kesempatan untuk menganalisis data asupan natrium pada penduduk Indonesia. Terima kasih juga kami ucapkan kepada Dr. Abas Basuni Jahari yang telah memberikan arahan dan saran pada analisis data. Ucapan terima kasih juga kami ucapkan kepada tim manajemen data yang telah membantu dalam mempersiapkan data.

\section{RUJUKAN}

1. Ramadan A. Gaya hidup masyarakat berisiko sebabkan kena penyakit tak menular. Kompas, 18 Mei 2015. http://print.kompas.com/baca/2015/05/18/
2. He FJ, Mac Gregor. Comprehensive review on salt and health and current experience of worlwide salt reduction programmes. $J$ Hypertens. 2009; 23: 363-84.

3. Kementerian Kesehatan, Badan Penelitian dan Pengembangan Kesehatan. Laporan Nasional: Riset Kesehatan Dasar (Riskesdas) 2007. Jakarta: Balitbangkes Kemenkes Rl; 2008.

4. Kementerian Kesehatan, Badan Penelitian dan Pengembangan Kesehatan. Laporan Nasional: Riset Kesehatan Dasar (Riskesdas) 2013. Jakarta: Balitbangkes Kemenkes Rl; 2014.

5. Rahajeng $E$, Tuminah S. Prevalensi hipertensi dan determinannya di Indonesia. Maj Kedokt Indon. 2009; 59(12):580-7.

6. Anggara FHD, Prayitno N. Faktor-faktor yang berhubungan dengan tekanan darah di Puskesmas Telaga Murni Cikarang Barat tahun 2012. Jurnal IImiah Kesehatan 2013: $5(1)$

7. Elliott $P$, Stamler J, Nichols $R$, Dyer $A R$, Stamler $\mathrm{R}$, Kesteloot $\mathrm{H}$, et al. Intersalt revisited: further analyses of 24 hour sodium excretion and blood pressure within and across populations. BMJ 1996; 312(7041):1249-53.

8. Permenkes RI No. 30 tahun 2013 tentang Pencantuman Informasi Kandungan Gula, Garam dan Lemak serta Pesan Kesehatan untuk Pangan Olahan dan Pangan Siap Saji.

9. Siswanto, dkk. Buku Survei Konsumsi Makanan Individu dalam Studi Diet Total Indonesia 2014. Jakarta: Badan Penelitian dan Pengembangan Kesehatan; 2014.

10. Institute of Medicine. Strategies to Reduce Sodium Intake in the United States. Washington, DC: Institute of Medicine of the National Academies; 2010.

11. Gunn JP, Blair NA, Cogswell ME, Merritt RK, Labarthe DR, Curtis CJ, et al. CDC grand rounds: dietary sodium reduction time for choice. MMWR Morb Mortal Wkly Rep. 2012; 61(05);89-91.

12. Whelton PK, Appel LJ, Sacco RL, Anderson CA, Antman EM, Campbell N, et al. Sodium, blood pressure, and cardiovascular disease: further evidence supporting the American Heart Association sodium reduction recommendations. Circulation. 2012; 126(24): 2880-9. 
13. He FJ, MacGregor GA. Salt intake and cardiovascular disease. Nephrol Dial Transplant. 2008;23:3382-5 (doi: 10.1093/ndt/gfn550)

14. Webster JL, Dunford EK, Neal BC. A Systematic survey of the sodium contents of processed foods. Am J Clin Nutr. 2010; 91:413-20.

15. James WP, Ralph A, Sanchez-Castillo CP. The dominance of salt in manufactured food in the sodium intake of affluent societies. Lancet. 1987; 1(8530):426-9.

16. Mattes RD, Donnelly D. Relative contributions of dietary sodium sources. J Am Coll Nutr. 1991; 10: 383-393.

17. Elliott P, Brown I. Sodium Intakes around the World. Background document prepared for the Forum and Technical Meeting on Reducing Salt Intake in Populations (Paris 5-7th October 2006). WHO; 2007.

18. WHO. Guideline: Sodium intake for adults and children. Geneva: WHO; 2012.

19. Mozaffarian D, Fahimi S, Singh GM, Micha R, Khatibzadeh S, Engell RE, et al. Global sodium consumption and death from cardiovascular causes. N Engl J Med. 2014; 371: 624-34.

20. WHO. Salt as a Vehicle for Fortification. Report of a WHO Expert Consultation. Geneva: WHO, 2008.

21. Campbell NRC, Johnson JA, Campbell TS. Sodium consumption: an individual's choice? Int J Hypertens. 2012; 6 pages (doi:10.1155/2012/860954).

22. Sasaki N. The salt factor in apoplexy and hypertension: epidemiology studies in Japan. In: Yamori Y, Ed. Prophylactic
Approach to Hypertensive Diseases. New York: Raven Press, 1979. 467-74

23. Karppanen $\mathrm{H}$, Mervaala E. Sodium intake and hypertension. Prog Cardiovasc Dis. 2006; 49(2): 59-75.

24. Pietinen $P$, Valsta LM, Hirvonen T, Sinkko $\mathrm{H}$. Labelling the salt content in foods: a useful tool in reducing sodium intake in Finland. Public Health Nutr. 2008; 11(4): 335-40.

25. Laatikainen $T$, Pietinen $P$, Valsta $L$, Sundvall J, Reinivuo $H$, Tuomilehto J. Sodium in the Finnish diet: 20-year trends in urinary sodium excretion among the adult population. Eur J Clin Nutr. 2006; 60(8): 965-70.

26. The China Salt Substitute Study Collaborative Group. Salt substitution: a low-cost strategy for blood pressure control among rural Chinese: a randomized, controlled trial. J Hypertens. 2007; 25(10): 2011-8.

27. Mu J, Liu Z, Liu F, Xu X, Liang Y, Zhu D. Family-based randomized trial to detect effects on blood pressure of a salt substitute containing potassium and calcium in hypertensive adolescents. Am J Hypertens. 2009; 22(9): 943-7.

28. Institute of Medicine. Strategies to Reduce Sodium Intake in the United States. Washington, DC: the National Academies Press, 2010.

29. Asaria P, Chisholm D, Mathers C, Ezzati M, Beaglehole R. Chronic disease prevention: health effects and financial costs of strategies to reduce salt intake and control tobacco use. Lancet. 2007; 370(9604): 2044-53. 